\title{
BEM-ESTAR ANIMAL: UM CONCEITO ECONÔMICO-BUROCRÁTICO, CRITÉRIO DE CONDUTA ÉTICA OU RESPEITO A SENCIÊNCIA DOS SERES?
}

\author{
(Animal welfare: an economic-bureaucratic consensus, criteria for ethical conduct or respect for sentience \\ of beings?) \\ ${ }^{1}$ Laís Cristine Werner, ${ }^{2}$ Pedro Vicente Michelotto Junior
}

${ }^{1}$ UNICENTRO, Brasil. ²Pontifícia Universidade Católica do Paraná (PUC-PR), Brasil.

*Correspondência: lais.werner@cctg.com.br

RESUMO: Nos últimos anos muito se tem discutido sobre o óbice relacionado ao bem-estar animal (BEA) e fatores de interesse estritamente humanos, e aqui cabe a elucubração: nesse impasse sobre interesses, a quem seria mais justo a condição de interessado? E a quem careceria da condição sujeita a determinado interesse? Como no processo de submissão de pesquisas dentro do meio científico há de se declarar a ausência de conflitos de interesse, não seria justo aqueles que protagonizam esses estudos também pudessem ter o amparo da declaração? Dentro da temática que mais abarca as razões conflitantes no conceito de bemestar está a produtividade e suas implicações estendidas principalmente a economia pecuária. A avaliação do modo como se conduz o intento produtivo deve se fazer díade ao estado que os animais se encontram em relação às suas tentativas de se adaptar ao seu ambiente de forma verdadeira. A postulação de medidas sanitárias, quando se avalia a condução comercial de alguns países da comunidade internacional, que não incluem o BEA como referência válida nas negociações e o impacto que a ausência desta preocupação pode imprimir na comercialização dentro de alguns mercados pecuários é expressivo, visto que o mercado vem reduzindo a aceitação de produtos de origem animal às custas de sofrimento, representando a inelasticidade da demanda por produção conceituada no BEA. Questões ético-morais denotam reflexão por parte dos consumidores, mas o principal escopo ainda reside dentro da porteira. É imprescindível tratar os princípios norteadores do manejo animal imbuídos de verdadeira consciência ambiental. Darwin (1890) redigiu que nas faculdades mentais não existem diferenças fundamentais entre o homem e os animais, tanto um quanto outro exibem sensações como dor, felicidade e sofrimento. Sendo um mecanismo orgânico importante, a dor se apresenta como condição substancial para sobrevivência, porém a inércia no intento do auxílio e da possibilidade de cessação do agente causador já torna imoral a essência dos princípios norteadores da ideal condição humana. Como seres sencientes que são e por terem sido depositados sob a tutela da humanidade é urgente a necessidade de triunfar sobre a inércia proativa. Quanto maior grau de dificuldade apresentado pelo animal ao tentar interagir e "pertencer" a determinado ambiente, mais comprometido assenta-se o BEA. Adaptar-se ao meio não significa bem-estar. Estudos já viabilizam a avaliação observacional dessa relação através de escalas que estimam sinais, movimentos e outras circunstâncias que o indivíduo expressa incluso na situação que vive, o que muito contribui no auxílio da tomada de decisões. Situações conflitantes que implicam valores e princípios éticos requerem apoderação de escolhas. $O$ sofrimento de caráter iatrogênico vai muito além da percepção (bio)ética. A interessante alegoria descrita por Broom (2011) deveria constantemente figurar na mente humana: um coelho é visto de forma diferente conforme é considerado, ora um animal de estimação da família, ora animais de laboratório, ora animais criados no aspecto produtivo de carne e ora um animal selvagem que se alimenta de suas colheitas. Isso não é cientificamente sólido. Um coelho é um coelho.

Palavras-chave animais; BEA; produção; sofrimento. 


\section{Referências}

BROOM, D.M. Bem-estar animal. In: YAMAMOTO, M.E.; VOLPATO, G.L. Comportamento Animal. 2. ed. Natal, RN: Editora da UFRN, 2011. p. 457-482.

DARWIN, C. The expression of the emotions in man and animals. 2. ed. London: John Murray, 1890 